\title{
Bovine brucellosis: epidemiological situation in Brazil and disease control initiatives
}

\author{
Brucelose bovina: \\ situação epidemiológica do Brasil e iniciativas no combate à doença
}

\author{
Inácio José Clementino; ${ }^{1}$ Sérgio Santos de Azevedo ${ }^{2 *}$
}

\begin{abstract}
Bovine brucellosis caused by Brucella abortus is present throughout Brazil, whose prevalence distribution shows variations among states and within the productive areas of the states, causing serious losses to cattle production and public health due to risk of transmission to humans. Therefore, since 2001, the National Program for the Control and Eradication of Brucellosis and Tuberculosis (PNCEBT) is being implemented in all Federative Units of Brazil, based on the compulsory vaccination of bovine females, control of animal movement and certification of brucellosis-free herds. This review covers the current epidemiological situation of bovine brucellosis in Brazil, issues related to public health and economic importance, as well as Brazilian initiatives to control the disease.
\end{abstract}

Key words: Bovine brucellosis. PNCEBT. Epidemiological situation. Eradication.

\section{Resumo}

A brucelose bovina causada pela Brucella abortus está presente em todo o território brasileiro, cuja distribuição das prevalências apresenta variações entre os estados e dentro das regiões produtivas dos estados, causando sérios prejuízos à bovinocultura e à saúde pública devido ao risco de transmissão ao homem. Por isso, desde o ano de 2001, está sendo implantado, em todas as Unidades Federativas do Brasil, o Programa Nacional de Controle e Erradicação da Brucelose e Tuberculose (PNCEBT), baseado na vacinação obrigatória das fêmeas, controle do trânsito de animais e certificação de propriedades como livres da doença. Esta revisão aborda a situação epidemiológica atual da brucelose bovina no Brasil, aspectos relacionados à importância econômica e saúde pública, bem como as iniciativas brasileiras para controle da doença.

Palavras-chave: Brucelose bovina. PNCEBT. Situação epidemiológica. Erradicação.

\footnotetext{
${ }^{1}$ Discente do Curso de Doutorado do Programa de Pós-Graduação em Medicina Veterinária, Universidade Federal de Campina Grande, UFCG, Patos, PB, Brasil. E-mail: clementinoij@yahoo.com.br

${ }^{2}$ Prof., Programa de Pós-Graduação em Medicina Veterinária, UFCG, Patos, PB, Brasil. E-mail: sergio@vps.fmvz.usp.br

* Author for correspondence
} 


\section{Introduction}

Bovine brucellosis, caused by Brucella abortus, is present in all Brazilian regions (PAULIN; FERREIRA NETO, 2003) with a prevalence of $0.32 \%$ for property and $0.06 \%$ for animals in the state of Santa Catarina (SIKUSAWA et al., 2009) and $>40 \%$ for farms and $10 \%$ for seropositive animals in the states of Mato Grosso do Sul and Mato Grosso (CHATE et al., 2009; NEGREIROS et al., 2009), showing heterogeneous distribution prevalence among states and even in regions within some states.

Due to the high economic losses caused by brucellosis (FARIA, 1984; CORBEL, 1997; SANTOS et al., 2013) and severe trade restrictions to the international market for animals and products of animal origin, countries in which the disease occurs seek to formulate and implement control and eradication programs (FENSTERBANK, 1986; PAULIN; FERREIRA NETO, 2003). Several countries have shown that the costs of bovine brucellosis control and eradication programs are lower than the losses arising from disease occurrence (CAPORALE et al., 1980; SHEPHERD et al., 1980; CAMPOS et al., 1993; BERNUÉS et al., 1997).

In Brazil, the effective control of bovine brucellosis with territorial extension began in 2001 with the establishment of the National Program for Control and Eradication of Brucellosis and Tuberculosis (NPCEBT), whose current regulation was approved in 2004 (BRASIL, 2004, 2006). This program is based on the adoption of compulsory measures such as vaccination of calves against brucellosis and the traffic control of animals destined for breeding, both of which have proven effective (FENSTERBANK., 1986; AMAKU et al., 2009), as well as voluntary adhesion measures such as disease-free property certification and disease monitoring.

For NPCEBT evaluation, it is extremely important to identify the epidemiology of bovine brucellosis since it enables the selection of appropriate strategies that may differ according to disease frequency and distribution. To meet this requirement, several states have conducted seroepidemiological studies to elucidate brucellosis distribution and prevalence. Their results are presented in this review, which was developed to describe the epidemiological situation and control initiatives of bovine brucellosis in Brazil.

\section{Economic impact}

Direct losses from bovine brucellosis result from abortions, low reproductive rates, increased calving intervals, decreased meat and milk production, calf mortality, and the disruption of genetic lineages. Estimates show that infection is responsible for 20$25 \%$ decreased milk production, $10-15 \%$ decreased meat production, $15 \%$ calf loss due to abortion, $30 \%$ increased animal replacement rate, and an inter-delivery interval increase of 11.5-20 months. In addition, one of every five infected cows aborts or becomes permanently sterile (FARIA, 1984; BERNUÉS et al., 1997).

In Central America, economic losses were estimated as 25 million dollars annually (MORENO, 2002). In Paraguay, the estimated economic cattle herd loss amounts to 23.5 million dollars (BAUMGARTEN, 2002); in Argentina, these losses approach 60 million dollars (SAMARTINO, 2002). In Latin America, the annual losses due to bovine brucellosis were estimated at $600-700$ million dollars, with Brazil having half of that amount (FARIA, 1984), values very close to the estimated values for the 1990s by the United States Department of Agriculture, in which the annual loss in Latin America was evaluated at 600 million dollars (CORBEL, 1997).

In Brazil, there was an estimated loss of at least 30 million dollars due to animal brucellosis in 1982 (OIE, 1987). Only for the city of Pirassununga, São Paulo State, Homem (2003) estimated an annual economic impact of up to $132,676.23$ real in 2001 . 
In a simulation of the annual economic impact of bovine brucellosis in dairy farms of Minas Gerais and Goiás States, the estimated loss was around $13 \%$ of the total property revenue, $5 \%$ for the states of Santa Catarina and Rio Grande do Sul, and even in regions with low prevalence, the economic impact caused by the infection compromised a large proportion of producer profitability (LUCAS, 2006).

In the most recent and comprehensive estimate of the economic losses caused by bovine brucellosis in Brazil, the amount is 420.12 and 226.47 real for each cow infected in milk and meat production, respectively, totaling a 892-million-real loss to the country (equivalent to 448 million dollars at the time of the study). However, it is noteworthy that for every $1 \%$ change in prevalence, a variation of 155 million real in the cost of bovine brucellosis in Brazil is estimated (SANTOS et al., 2013).

In Mexico, it was estimated that in herds undergoing subprograms involving the removal of positive animals, the mean annual loss per animal was 33.58 dollars, a statistically significant difference from herds that only performed the vaccination of females without removing positive animals, which showed an average loss of $\$ 70.00$ per animal (CAMPOS et al., 2010). This shows that the female vaccination control program and elimination of positive animals is significantly more economical than allow them to remain in the herd, especially if the disease prevalence is low. In the region of Narinõ, Colombia, Astaiza-Martínez et al. (2012) reported that the total cost per vaccinated heifer in a bovine brucellosis vaccination program was 12,200 Colombian pesos (14.36 real; calculation performed on $03 / 12 / 2013)$.

The international experience has shown that control and eradication costs of bovine brucellosis programs are lower than the losses arising from disease occurrence (CAPORALE et al., 1980; SHEPHERD et al., 1980; CAMPOS et al., 1993, 2010; BERNUÉS et al., 1997; ASTAIZA-
MARTÍNEZ et al., 2012). Classic examples are Italy and Canada, where it was estimated that for every dollar invested in the control and eradication program, a return of 4.5 and 5 dollars occurred, respectively (FERREIRA NETO, 1998).

A practical example is the Czech Republic, which managed to eradicate brucellosis in 1965; 10 years post-eradication, the cumulative cost/ benefit was 1:7. Consequently, by the year 2000, approximately 700 million dollars in losses was avoided and $>2,000$ people were protected from this zoonosis (KOUBA, 2003).

\section{Importance in public health}

Human brucellosis is an occupational disease with a geographic distribution that coincides with animal endemism (PESSEGUEIRO et al., 2003). Risk groups include veterinary staff(VILLARROEL et al., 2000), farmers and rural workers (SANTOSNETO et al., 1999; FERREIRA et al., 2002; DRAGOSAVAC et al., 2007; MELO et al., 2007), and slaughterhouse workers (RAMOS et al., 2008), and since it can be excreted in the milk and survive for long periods in both milk and contaminated products (LANGONI et al., 2000; MIYASHIRO et al., 2007), the disease can be conveyed to consumers.

The disease incidence in humans is poorly understood (CORBEL, 1997), but human susceptibility to brucellosis has great importance because the World Health Organization (WHO) estimates that 500,000 new cases arise each year with a limited geographical distribution, but it remains a public health problem in the Mediterranean, western Asia, parts of Africa, and Latin America (BRASIL, 2006; PAPPAS et al., 2006).

Currently, according to the WHO, even in developed countries, the true incidence of brucellosis may be five or more times higher than the official figures. This fact is attributed to underdiagnosis and underreporting (LAWINSKY et al., 2010). In Brazil, according to the System of Hospital 
Information of the public health system (SUS) - SIH/SUS (BRASIL, 2014) of the Ministry of Health, from January 2008 to December 2013, there were 176 hospitalizations due to brucellosis under SUS, 24 in the North region, 27 in the Northeast, 56 in the Southeast, 61 in the South, and eight in the Midwest. The mean length of hospital stay for brucellosis in Brazil during this period was 9.5 days. Four deaths occurred over the same period: one in the Northeast, one in the Southeast, and two in the South region.

In 1956, human brucellosis was declared a rural endemism of compulsory notification by veterinarians, whose cases should be investigated and battled (BRASIL, 1956, 1961, 1965).

Humans acquire brucellosis directly by contacting infected animals or indirectly by eating animal products, mainly raw milk. Airborne transmission has also been observed (DOGANAY; AYGEN, 2003). The incubation period varies at 1-5 weeks; however, it can persist for months, and this is a septicemic disease of a sudden-onset or insidious nature. In the acute phase, the main clinical symptoms are continuous or intermittent fever, chills, muscle and abdominal pain, arthritis, insomnia, headache, profuse sweating and malaise; in the chronic phase, neuropsychiatric impairment is frequent, with irritability, nervousness, and depression. Its major complications include endocarditis, myocarditis, pericarditis, meningitis, arthritis, hepatitis, and visceral abscesses (HARTIGAN, 1997; DOGANAY; AYGEN, 2003; LAWINSKY et al., 2010). These clinical manifestations are responsible for patients' partial or complete inability to work and mentioned in the list of work-related diseases of the Ministry of Health (Brucellosis A23) (LAWINSKY et al., 2010).

\section{Geographic distribution and prevalence}

Brucellosis caused by B. abortus is distributed worldwide but concentrated in developing countries. The highest incidence of bovine brucellosis occurs in the Middle East, Mediterranean region, subSaharan Africa, China, India, Peru, and Mexico. Currently, the growth in the number of cases occurs in Southeast and Central Asia countries. Several countries in Western Europe and North America, as well as Canada, Japan, Australia, and New Zealand, are free of bovine brucellosis (OIE, 2013) and the Czech Republic (KOUBA, 2003), showing that the current state of infection worldwide varies in response to sanitary, socioeconomic, and political situations, highlighting the lack of knowledge of sanitary status by the lack of prevalence studies (PAPPAS et al., 2006).

A diagnosis of the state of domestic bovine brucellosis performed in 1975 revealed that the estimated percentage of positive animals was $4 \%$ in the South, $7.5 \%$ in the Southeast, $6.8 \%$ in the Midwest, $2.5 \%$ in the Northeast, and $4.1 \%$ in the North. Data from official reports indicate that the prevalence of seropositive animals remained at 4-5\% from 1988 to 1998 . The 1975 study cited the prevalence of seropositive animals in 18 states. All states in the Northeast region examined their animals and presented the following seropositive frequencies: Paraíba and Rio Grande do Norte, $0.8 \%$; $1.3 \%$, Maranhão; Piauí, 0.2\%; Ceará, 0.6\%; Pernambuco, 1.5\%; Alagoas, 0.9\%; Sergipe, 10.5\%; and Bahia, 6.2\% (PAULIN; FERREIRA NETO, 2003).

After the implementation of the National Program for Control and Eradication of Brucellosis in 2001 (BRASIL, 2006), the federal units began conducting standardized studies of the epidemiological characterization of bovine brucellosis. Studies have been published from 17 states, while others are in progress. Table 1 shows the results of outbreak prevalence (properties with at least one seropositive animal) and seropositive animals obtained to date. 
Table 1. Prevalence of outbreak and seropositive animals for brucellosis in the Brazilian states that completed a seroepidemiological study of bovine brucellosis.

\begin{tabular}{cccc}
\hline State & $\begin{array}{c}\text { Prevalence of outbreak } \\
(\%)\end{array}$ & $\begin{array}{c}\text { Prevalence in animals } \\
(\%)[95 \% \text { CI }]\end{array}$ & Authors \\
& {$[95 \% \mathrm{CI}]$} & -- & \\
\hline Mato Grosso do Sul & $41.5[36.5-44.7]$ & $12.6[9.1-17.2]$ & (CHATE et al., 2009) \\
MS - Pantanal - beef & $59[52.8-64.9]$ & $4.5[2.1-9.0]$ & \\
MS - Planalto - beef & $40.6[35.8-45.5]$ & -- & (NEGREIROS et al., 2009) \\
MS - Planalto - milk & $33.1[28.4-38.1]$ & $10.2[7.4-13.1]$ & (VILLAR et al., 2009) \\
\hline Mato Grosso & $41.2[38.0-44.4]$ & $6.2[4.9-7.6]$ & (OGATA et al., 2009) \\
\hline Rondônia & $35.2[32.1-38.4]$ & $4.4[3.6-5.3]$ & (ROCHA et al., 2009) \\
\hline Tocantins & $21.2[19.3-23.1]$ & $3.0[2.7-3.3]$ & (SILVA et al., 2009) \\
\hline Goiás & $17.5[14.9-20.2]$ & $4.1[2.8-5.3]$ & (KLEIN-GUNNEWIEK et al., 2009) \\
\hline Rio de Janeiro & $15.4[12.9-17.9]$ & $3.4[2.3-4.4]$ & (AZEVEDO et al., 2009) \\
\hline Sergipe & $12.6[9.2-16.0]$ & $3.8[0.7-6.9]$ & (GONÇALVES et al., 2009b) \\
\hline São Paulo & $9.7[7.8-11.6]$ & $3.5[1.9-6.4]$ & (DIAS et al., 2009a) \\
\hline Espírito Santo & $9.0[7.0-11.6]$ & $1.09[0.78-1.41]$ & (GONÇALVES et al., 2009a) \\
\hline Minas Gerais & $6.04[4.98-7.1]$ & $1.7[1.1-2.4]$ & (MARVULO et al., 2009) \\
\hline Paraná & $4.0[3.2-4.8]$ & $0.16[0.04-0.28]$ & (SIKUSAWA et al., 2009) \\
\hline Federal District & $2.5[1.0-5.1]$ & $1.0[0.6-1.4]$ & (BORBA et al., 2013) \\
\hline Rio Grande do Sul & $2.1[1.5-2.6]$ & $0.06[0.0-0.99]$ & (CLEMENTINO, 2014) \\
\hline Santa Catarina & $0.32[0.10-0.69]$ & $2.52[1.73-3.65]$ & (ALMEIDA, 2013) \\
\hline Maranhão & $11.42[9.23-14.06]$ & $2.0[1.1-3.9]$ & (ALVES et al., 2009) \\
\hline Paraíba & $4.6[3.2-6.5]$ & $1.4[0.72-2.06]$ &
\end{tabular}

The prevalence of both outbreaks and seropositive animals varied among states; within the same state, it varied among production areas, with the lowest prevalence observed in the state of Santa Catarina (SIKUSAWA et al., 2009) with $0.32 \%$ of outbreaks and $0.06 \%$ of animals and the largest in the states of Mato Grosso do Sul and Mato Grosso (CHATE et al., 2009; NEGREIROS et al., 2009) with $>40 \%$ of properties and $>10 \%$ of animals testing seropositive.

\section{Risk and protection factors}

The occurrence and distribution of bovine brucellosis can be influenced by many extraneous factors. The introduction of animals to the herd is a classic risk factor that is considered important in the disease epidemiology (SALMAN; MEYER, 1984). In general, the higher the frequency of new animal introductions, the higher the risk of introducing infected individuals (CRAWFORD et al., 1990), meaning that infection occurrence is increased in herds in which replacements comprise external sources compared to that of closed systems (GIL TURNES et al., 1975). The increase in herd size is usually accompanied by increased density of animals, which favors the spread of infection, especially for feedlot cattle, particularly after episodes of abortion (NICOLETTI, 1980).

Other factors that may increase the risk of disease introduction in cattle farming include the proximity of infected herds and the use of shared pastures and water sources (rivers and ponds) (NICOLETTI, 1980; SALMAN; MEYER, 1984; CRAWFORD et al., 1990). On the other hand, practices such as immunizing females at 3-8 months of age and the use of enclosures for females in the delivery and postpartum periods decrease the likelihood of infection exposure due to a substantial reduction in susceptibility to infection, and decrease the contamination of pastures and facilities (NICOLETTI, 1980; CRAWFORD et al., 1990). 
Table 2. Risk factors of bovine brucellosis distribution by state.

\begin{tabular}{|c|c|c|c|c|}
\hline State & Risk factor & Odds ratio & $\begin{array}{c}\text { Confidence } \\
\text { interval (95\%) }\end{array}$ & Author(s) \\
\hline \multirow[t]{2}{*}{ Bahia } & Purchase of breeders & 2.27 & {$[1.22-4.21]$} & \multirow{2}{*}{ (ALVES et al., 2009) } \\
\hline & Wetlands & 1.76 & {$[1.02-3.05]$} & \\
\hline \multirow{2}{*}{ Espírito Santo } & Artificial insemination & 7.05 & {$[2.51-19.8]$} & \multirow{2}{*}{ (AZEVEDO et al., 2009) } \\
\hline & Confinament/semiconfinament & 2.98 & {$[2.98-7.26]$} & \\
\hline \multirow{3}{*}{ Goiás } & Record of abortions & 5.83 & {$[3.86-8.81]$} & \multirow{3}{*}{ (ROCHA et al., 2009) } \\
\hline & Vaccine against brucellosis & 2.07 & {$[1.38-3.09]$} & \\
\hline & Purchase of breeders & 2.06 & {$[1.21-3.52]$} & \\
\hline \multirow{3}{*}{ Minas Gerais } & Deer in the property & 1.56 & {$[1.08-2.27]$} & \multirow{3}{*}{ (GONÇALVES et al., 2009b) } \\
\hline & Purchase of breeders & 1.66 & {$[1.13-2.44]$} & \\
\hline & Record of abortions & 1.81 & {$[1.26-2.60]$} & \\
\hline \multirow{2}{*}{ Mato Grosso do Sul } & Herd with $>500$ cows & 2.46 & {$[1.81-3.34]$} & \multirow{2}{*}{ (CHATE et al., 2009) } \\
\hline & Occurrence of weak calves & 1.20 & [0.87-1.65] & \\
\hline \multirow{3}{*}{ Mato Grosso } & Mix and beef type operation & 1.8 and 1.8 & {$[1.20-2.70]$} & \multirow{3}{*}{ (NEGREIROS et al., 2009) } \\
\hline & Herd with $>11$ cows & $>4.8$ & {$[1.1-20.9]$} & \\
\hline & Record of abortions & 1.7 & {$[1.30-2.20]$} & \\
\hline \multirow{2}{*}{ Paraná } & Purchase of breeders & 2.20 & {$[1.42-3.40]$} & \multirow{2}{*}{ (DIAS et al., 2009a) } \\
\hline & Rent of pastures & 2.53 & {$[1.54-3.90]$} & \\
\hline \multirow{3}{*}{ Rio de Janeiro } & Herd with $>30$ cows & 2.33 & {$[1.62-3.32]$} & \multirow{3}{*}{$\begin{array}{l}\text { (KLEIN-GUNNEWIEK et al., } \\
\text { 2009) }\end{array}$} \\
\hline & Purchase of breeders & 1.95 & {$[1.36-2.79]$} & \\
\hline & Rent of pastures & 1.74 & {$[1.06-2.85]$} & \\
\hline \multirow{2}{*}{ Rondônia } & Record of abortions & 1.42 & [1.04-1.94] & \multirow{2}{*}{ (VILLAR et al., 2009) } \\
\hline & Beef type operation & 1.75 & {$[1.29-2.37]$} & \\
\hline \multirow{2}{*}{ Rio Grande do Sul } & Beef type operation & 4.27 & {$[1.82-10.0]$} & \multirow{2}{*}{ (MARVULO et al., 2009) } \\
\hline & Record of abortions & 3.27 & {$[1.71-6.25]$} & \\
\hline \multirow{3}{*}{ Sergipe } & Herd with $>30$ cows & 1.88 & {$[1.07-3.28]$} & \multirow{3}{*}{ (SILVA et al., 2009) } \\
\hline & Veterinary assistance & 2.89 & {$[1.15-7.23]$} & \\
\hline & Use of artificial insemination & 1.92 & [0.84-4.38] & \\
\hline \multirow{2}{*}{ São Paulo } & Herd with $>87$ bovines & 2.25 & {$[1.47-3.44]$} & \multirow{2}{*}{ (DIAS et al., 2009b) } \\
\hline & Purchase of breeders & 1.56 & {$[1.03-2.36]$} & \\
\hline \multirow{2}{*}{ Tocantins } & Herd with $>120$ cows & 2.00 & {$[1.51-2.63]$} & \multirow{2}{*}{ (OGATA et al., 2009) } \\
\hline & Slaughter of breeders & 1.52 & [1.15-1.99] & \\
\hline \multirow{3}{*}{ Pernambuco } & Herd with $>21$ bovines & 3.73 & {$[1.75-7.95]$} & \multirow{3}{*}{ (ALMEIDA, 2013) } \\
\hline & Presence of flooded pastures & 2.58 & {$[1.22-5.47]$} & \\
\hline & Record of abortions & 2.81 & {$[1.07-7.35]$} & \\
\hline & Herds with $>54$ cows & 4.08 & {$[2.47-2.73]$} & \\
\hline Maranhão & Rent pastures for third parties & 1.83 & {$[1.07-3.13]$} & (BORBA et al., 2013) \\
\hline & Presence of flooded areas & 1.66 & {$[1.00-2.74]$} & \\
\hline
\end{tabular}

Few recent international studies aimed to determine risk factors for bovine brucellosis. OMER et al. (2000), in Eritrea, found that the risk factor associated with the prevalence of bovine brucellosis was to create crossbred animals, with an odds ratio (OR) of 5.21 (95\% confidence interval [CI], 1.4518.7), which was justified by the high frequency of purchased animals on properties that create crossbred animals. In Sri Lanka, the risk factors were the presence of animals $>3$ years of age (OR, 2.0; 95\%
CI, 1.4-2.8), animals coming from dry areas (OR, 5.0; 95\% CI, 3.6-7.0), and extensive farming (OR, 1.8; 95\% CI, 1.2-2.5) (SILVA et al., 2000).

In Brazil, risk factors analyses were performed in some states that included seroepidemiological surveys of bovine brucellosis after the implementation of NPCEBT (Table 2). According to those studies, the most common risk factors were the purchase of breeding herds, herds with $>11$ cow and pasture rentals, presence of wetlands on the 
property, and an abortion history. These data were evaluated by MOTA (2011), and the final logistic regression model revealed that the main variables associated with the presence of brucellosis are the purchase of breeder animals and the number of females on the property.

Vaccination against brucellosis, the use of artificial insemination, and the presence of calving enclosures were cited as protective factors in seroepidemiological studies conducted in Brazil (Table 3). It should be noted that the association of calf vaccination and the reduction of brucellosis proves the efficiency of this preventive measure (ALVES et al., 2009; AMAKU et al., 2009; AZEVEDO et al., 2009; GONÇALVES et al., 2009b; OGATA et al., 2009). However, when vaccination appears as a risk factor, it can usually be explained by the large number of owners who begin to vaccinate only after brucellosis is identified in the herd, suggesting that it is a consequence of infection (ROCHA et al., 2009).

Artificial insemination is traditionally a protective factor against brucellosis infection because it is associated with a higher level of livestock-related technology (GONÇALVES et al., 2009b), and breeding semen suppliers adhere to strict sanitary control measures, including being free of $B$. abortus. However, when semen is obtained in homemade exchanges in which donors are not subjected to strict sanitary control, artificial insemination may contribute to the spread of bovine brucellosis (AZEVEDO et al., 2009).

Table 3. Protective factors of bovine brucellosis found in serological studies conducted in Brazil.

\begin{tabular}{llccl}
\hline State & Risk factor & $\begin{array}{c}\text { Odds } \\
\text { ratio }\end{array}$ & $\begin{array}{c}\text { Confidence } \\
\text { interval (95\%) }\end{array}$ & Author(s) \\
\hline Bahia & Vaccination up to 8 months & 0.53 & {$[0.29-0.96]$} & (ALVES et al., 2009) \\
Espírito Santo & Vaccination up to 8 months & 0.03 & {$[0.01-0.1]$} & (AZEVEDO et al., 2009) \\
Minas Gerais & Vaccination up to 8 months & 0.38 & {$[0.19-0.79]$} & (GONÇALVES et al., 2009b) \\
Mato Grosso do Sul & Use of artificial insemination & 0.71 & {$[0.50-1.01]$} & (CHATE et al., 2009) \\
& Vaccination up to 8 months & 0.37 & {$[0.28-0.50]$} & \\
Tocantins & Parturition enclosures & 0.72 & {$[0.55-0.94]$} & (OGATA et al., 2009) \\
& Milk type operation & 0.63 & {$[0.45-0.88]$} & \\
Maranhão & Beef type operation & 0.45 & {$[0.26-0.76]$} & (BORBA et al., 2013) \\
\hline
\end{tabular}

History of the Brazilian initiative to combat disease

Bovine brucellosis control programs have been recommended since 1896 , but it was not until the 1930 s that their implementation started to occur in a greater number of countries (PAULIN; FERREIRA NETO, 2003). The economic losses caused by the disease and the ability to control or eradicate it associated with the prevention of human infection justify the adoption of control programs. Some well-structured national programs successfully eradicated brucellosis in several countries (FENSTERBANK, 1986).
In Brazil, by 1934, bovine brucellosis was already declared subject to animal health protection measures demanding diagnostic tests in the entry for imports of bovine animal, the sacrifice of animals with brucellosis entered in the country, and the demand for negative clearance for brucellosis for interstate transit of breeders (BRASIL, 1934). Nevertheless, the first attempt at effective control of bovine brucellosis occurred in the year 1944 with Decree Law 6922, which established the identification of vaccinated animals (BRASIL, 1944). Later, other normative acts were published, but they did not cause great progress in disease 
control (POESTER et al., 2002). In 1954, a control program was recommended based on the model from the United States of America (plans A, B, C, and D) (PAULIN; FERREIRA NETO, 2003). In 1958, a national program was proposed to combat the disease whose strategies included vaccination of all heifers and organization of state and local commissions composed of agricultural organizations, farmers, meat and milk traders, public health departments, medical associations, and mass media (POESTER et al., 2002).

Ordinance № 23 dated January 20, 1976, of the Ministry of Agriculture, Livestock and Food Supply proposed a national program consisting of vaccinating females at 3-8 months of age, identifying outbreaks, performing testing, and voluntarily euthanizing reactors (POESTER et al., 2002). However, full program implementation has not yet occurred, while the epidemiological situation has remained the same with a high prevalence of the disease in most producing areas.

The NPCEBT was established in 2001 and then revised and approved in 2004 (BRASIL, 2004, 2006). This program aims to promote the quality of animal products offered to consumers, improving the image that the country projects on world markets and contributing to the modernization of milk and meat production chains. The objectives of the program are to: (a) lower the prevalence and incidence of new cases of brucellosis and tuberculosis; and (b) create a significant number of certified farms that offer consumer products with a low sanitary risk. To this end, the program action strategies include proven compulsory measures (females 3-8 months of age vaccinated against brucellosis and traffic control of breeding animals) (FENSTERBANK, 1986; AMAKU et al., 2009) as well as voluntary adhesion measures (certification of disease-free status and monitoring of properties).

In Brazil, the use of two vaccine types is allowed. Since program implementation, the vaccine with the B19 strain of B. abortus has been required and used for vaccinating 3-8-month-old female bovines, which should then be tagged (BRASIL, 2004). In 2007, the RB51 strain was approved for vaccinating bovine females $>8$ months of age (BRASIL, 2007), and its use is at the discretion of the veterinarian. However, the bovine brucellosis vaccine was prohibited in Santa Catarina (BRASIL, 2006) due to the low disease prevalence (SIKUSAWA et al., 2009).

Consequently, in 2012, the state of Santa Catarina was the first to start a specific program for the eradication of bovine brucellosis prohibiting the use of brucellosis vaccine with the B19 and RB51 strain vaccines can only be used via national veterinary service evaluation and approval. The properties identified as being related to a brucellosis outbreak will be interdicted and sanitized in addition to the surveillance and identification of properties with an epidemiological link to outbreaks per animal movement or intensive contact (SANTA CATARINA, 2012). It is noteworthy that in this state, there is a private fund for compensating producers whose animals died or had to be sacrificed owing to brucellosis infection.

Despite not being a specific point in the control and eradication program for bovine brucellosis, a good sanitary education strategy to raise awareness among farmers and the general population about the disease's importance and risks, prevention methods, and standard controls adopted in the country should be adopted at all program stages. A good surveillance system is also crucial for monitoring the program's progress, especially in the regions that have adopted or are in the process of adopting brucellosis eradication strategies.

\section{Final considerations}

Detailed analyses of the prevalence of bovine brucellosis in Brazil observed that, in addition to the state of Santa Catarina (SIKUSAWA et al., 2009), Northern Rio Grande do Sul, and Southern Parana (DIAS et al., 2009a; MARVULO et al., 2009) have 
very low prevalence $(<2 \%)$, which would highlight the effective start of the brucellosis eradication program (AMAKU et al., 2009), similar to the program started in state of Santa Catarina (SANTA CATARINA, 2012).

At the stage of implementing a brucellosis eradication program, it is necessary for the national veterinary service to be well structured with trained personnel and financial resources, preferably in the form of funds managed by the private sector, for compensating producers for disease-related losses. The active participation of cattle ranchers is also essential, which requires a reward system based on additional payments for products from certified disease-free farms with a quantitative increase in the number of certified disease-free properties and even regions.

Furthermore, there must be an investment in a good epidemiological surveillance system for brucellosis as a support tool in the disease control and eradication program. This surveillance should be increased to identify possible outbreaks and infected animals, especially in the regions in which disease eradication has already begun, beyond identification and monitoring of possible flaws in disease diagnosis made by qualified professionals to participate in the program.

The adoption of different strategies for a sanitary program within a state is a very complex task that requires a high degree of structuring of the national veterinary service, a great contribution of financial resources as well as a high level of farmer participation, well-structured official veterinary service, and tightly regulated production chain. For this reason, the states with high brucellosis prevalence must weave efforts to comply with the compulsory strategies of the NPCEBT of greater vaccine coverage of females and trafficking control of NPCEBT breeders (BRASIL, 2004).

The vaccination results are already proven and the vaccination rate $>70 \%$ significantly reduced the prevalence of infection, leaving it at a level that would enable the elimination of infected animals (FENSTERBANK, 1986). Mathematical models of bovine brucellosis vaccination showed that vaccination rates with $\mathrm{B} 19$ strain of $B$. abortus $>$ $70 \%$ for a period of $10-20$ years are sufficient to reduce the prevalence of brucellosis infection to $\leq 2 \%$. With the RB51 strain of B. abortus approved for vaccination of adult females (BRASIL, 2007), its proper use will shorten the time needed to obtain high vaccine coverage in the population of females of childbearing age and may contribute to a more rapid reduction in the prevalence of bovine brucellosis (AMAKU et al., 2009).

\section{Acknowledgements}

Conselho Nacional de Desenvolvimento Científico e Tecnológico (CNPq) for finantial support (codes 471571/2011-3, 302131/2012-4 and 476596/2013-0).

\section{References}

ALMEIDA, E. C. S. Situação epidemiológica da brucelose no Estado de Pernambuco. 2013. Tese (Doutorado em Ciência Veterinária) - Universidade Federal Rural de Pernambuco, Recife.

ALVES, A. J. S.; GONÇALVES, V. S. P.; FIGUEIREDO, V. C. F.; LÔBO, J. R.; BAHIENSE, L.; AMAKU, M.; FERREIRA, F.; FERREIRA NETO, J. S.; DIAS, R. A. Situação epidemiológica da brucelose bovina no Estado da Bahia. Arquivo Brasileiro de Medicina Veterinária e Zootecnia, Belo Horizonte, v. 61, p. 6-13, 2009. Suplemento 1.

AMAKU, M.; DIAS, R. A.; FERREIRA NETO, J. S.; FERREIRA, F. Modelagem matemática do controle de brucelose bovina por vacinação. Arquivo Brasileiro de Medicina Veterinária e Zootecnia, Belo Horizonte, v. 61, p. 135-141, 2009. Suplemento 1.

ASTAIZA-MARTÍNEZ, J. M.; BENAVIDES-MELO, J. C.; DIAZ-ROJAS, J. A. Estudio de costo-efectividad del programa de vacunación contra Brucella abortus en bovinos en el departamento de Nariño. Revista Colombiana de Ciencias Químico - Farmacéuticas, Bogotá, v. 41, n. 2, p. 167-186, 2012. 
AZEVEDO, S. S.; FERREIRA NETO, J. S.; DIAS, R. A.; FERREIRA, F.; AMAKU, M.; FIGUEIREDO, V. C. F.; LÔBO, J. R.; GONÇALVES, V. S. P.; SOUZA, A. C.; VASCONCELLOS, S. A. Situação epidemiológica da brucelose bovina no Estado do Espírito Santo. Arquivo Brasileiro de Medicina Veterinária e Zootecnia, Belo Horizonte, v. 61, p. 19-26, 2009. Suplemento 1.

BAUMGARTEN, D. Brucellosis: A short review of the disease situation in Paraguay. Veterinary Microbiology, Amsterdam, v. 90, n. 1-4, p. 63-69, 2002.

BERNUÉS, A.; MANRIQUE, E.; MAZA, M. T. Economic evaluation of bovine brucellosis and tuberculosis eradication programmes in a mountain area of Spain. Preventive Veterinary Medicine, London, v. 30, n. 2, p. 137-149, 1997.

BORBA, M. R.; STEVENSON, M. A.; GONÇALVES, V. S. P.; FERREIRA NETO, J. S.; FERREIRA, F.; AMAKU, M.; TELLES, E. O.; SANTANA, S. S.; FERREIRA, J. C. A.; LÔBO, J. R.; FIGUEIREDO, V. C. F.; DIAS, R. A. Prevalence and risk-mapping of bovine brucellosis in Maranhão State, Brazil. Preventive Veterinary Medicine, London, v. 110, n. 2, p. 169-176, 2013.

BRASIL. Governo Provisório da República dos Estados Unidos do Brasil. Decreto n 24. 548, de 3 de julho de 1934. Aprova o regulamento do serviço de defesa sanitária animal. Diário Oficial [da] União, Poder Executivo, Rio de Janeiro, 14 jul. 1934. Seção 1, p. 14250.

- Governo Provisório da República dos Estados Unidos do Brasil. Decreto-Lei n ${ }^{\circ}$ 6. 922, de 4 de outubro de 1944. Dispõe sobre a identificação do gado bovino vacinado contra o abôrto infeccioso e dá outras providências. Diário Oficia [da] União, Poder Executivo, Rio de Janeiro, 6 out. 1944, Seção 1, p. 17289.

Governo Provisório da República dos Estados Unidos do Brasil. Lei n ${ }^{\circ}$ 2. 743, de 6 de março de 1956. Cria o Departamento Nacional de Endemias Rurais no Ministério da Saúde e dá outras providências. Diário Oficia [da] União, Poder Executivo, Rio de Janeiro, 7 de mar. 1956. Seção 1, p. 4177.

Governo Provisório da República dos Estados Unidos do Brasil. Decreto ${ }^{\circ}$ 49. 974-A, de 21 de Janeiro de 1961. Regulamenta, sob a denominação de Código Nacional de Saúde, a Lei $n^{\circ}$ 2. 312, de 3 de setembro de 1954, de normas gerais sobre defesa e proteção da saúde. Diário Oficia [da] União, Poder Executivo, Rio de Janeiro, 28 nov. 1961, Seção 1, p. 761.

Governo Provisório da República dos Estados Unidos do Brasil. Decreto n ${ }^{\circ} 57.156$, de 3 de Novembro de 1965. Baixa Normas Técnicas Especiais para a profilaxia da Brucelose e dá outras providências. Diário
Oficia [da] União, Poder Executivo, Rio de Janeiro, 5 nov. 1965, Seção 1, p. 11356.

Ministério da Agricultura, Pecuária e Abastecimento. Departamento de Defesa Animal. Programa Nacional de controle e erradicação da brucelose e tuberculose (PNCEBT) - Manual técnico. Brasília: MAPA, 2006. 188 p.

Ministério da Agricultura, Pecuária e Abastecimento. Departamento de Defesa Animal. Instrução normativa $\mathrm{n}^{\circ} 6$, de 8 de janeiro de 2004 . Aprova o regulamento técnico do programa nacional de controle e erradicação da brucelose e tuberculose animal. Diário Oficia [da] União, Poder Executivo, Brasília, 12 jan. 2004. Seção 1, p. 6.

Ministério da Agricultura, Pecuária e Abastecimento. Departamento de Defesa Animal. Instrução normativa $n^{\circ} 33$, de 24 de agosto de 2007. Estabelece condições para a vacinação de fêmeas bovinas contra brucelose, utilizando vacina não indutora da formação de anticorpos aglutinantes, amostra RB51. Diário Oficia [da] União, Poder Executivo, Brasília, 28 ago. 2007. Seção 1, p. 6.

Ministério da Saúde. Morbidade do SUS por local de residência: Lista morbidade CID-10: Brucelose. Internações, Óbitos e Média de permanência em internação por ano processamento segundo Região. Brasília: DATASUS, 2014. Disponível em: <http:// tabnet.datasus.gov.br/cgi/tabcgi.exe?sih/cnv/nruf.def $>$. Acesso em: 17 jan. 2014.

CAMPOS, V. M. X.; ARANGO, C. J. J.; PESADO, F. A. Evaluación financiera de um programa de control de la brucelosis bovina em la Comarca Lagunera (1987 a 1990). Veterinaria México, Cidade do México, v. 24, n. 2, p. 127-134, 1993.

CAMPOS, V. M. X.; RUANO, M. P.; IZQUIERDO, A. C. Evaluación de las pérdidas económicas por eventos de falla reproductiva asociadas a brucelosis bovina en hembras y explotaciones de la cuenca lechera de Tizayuca, Hidalgo, México. Revista Cientifica Faculdad de Ciencias Veterinarias, Maracaibo, v. 20, n. 2, p. 190-195, 2010.

CAPORALE, V. P.; BATTELLI, G.; GHILARDI, G.; BIANCARDI, V. Evaluation of the costs and benefits of the control campaigns against bovine tuberculosis, brucellosis, foot-and-mouth disease and swine fever in Italy. Bulletin de l'Office International des Epizooties, Paris, v. 92, n. 5-6, p. 291-304, 1980.

CHATE, S. C.; DIAS, R. A.; AMAKU, M.; FERREIRA, F.; MORAES, G. M.; COSTA NETO, A. A.; MONTEIRO, L. A. R. C.; LÔBO, J. R.; FIGUEIREDO, 
V. C. F.; GONÇALVES, V. S. P.; FERREIRA NETO, J. S. Situação epidemiológica da brucelose bovina no Estado do Mato Grosso do Sul. Arquivo Brasileiro de Medicina Veterinária e Zootecnia, Belo Horizonte, v. 61, p. 46-55, 2009. Suplemento 1.

CLEMENTINO, I. J. Situação epidemiológica da brucelose bovina no Estado da Paraíba, Brasil. 2014. Tese (Doutorado em Medicina Veterinária) Universidade Federal de Campina Grande, Centro de Saúde e Tecnologia Rural, Patos.

CORBEL, M. J. Brucellosis: an overview. Emerging Infectious Diseases, Atlanta, v. 3, n. 2, p. 213-221, 1997.

CRAWFORD, R. P.; HUBER, J. D.; ADAMS, B. S. Epidemiology and surveillance. In: NIELSEN, K; DUNCAN J. R. (Org.). Animal brucellosis. Boca Raton: CRC Press, 1990. p. 317-361.

DIAS, J. A.; MÜLLER, E. E.; DIAS, R. A.; FREITAS, J. C.; AMAKU, M.; FERREIRA, F.; SILVA, M. C. P.; LÔBO, J. R.; FIGUEIREDO, V. C. F.; GONÇALVES, V. S. P.; FERREIRA NETO, J. S. Situação epidemiológica da brucelose bovina no Estado do Paraná. Arquivo Brasileiro de Medicina Veterinária e Zootecnia, Belo Horizonte, v. 61, p. 66-76, 2009a. Suplemento 1.

DIAS, R. A.; GONÇALVES, V. S. P.; FIGUEIREDO, V. C. F.; LÔBO, J. R.; LIMA, Z. M. B.; PAULIN, L. M. S.; GUNNEWIEK, M. F. K.; AMAKU, M.; FERREIRA NETO, J. S.; FERREIRA, F. Situação epidemiológica da brucelose bovina no Estado de São Paulo. Arquivo Brasileiro de Medicina Veterinária e Zootecnia, Belo Horizonte, v. 61, p. 118-125, 2009b. Suplemento 1.

DOGANAY, M.; AYGEN, B. Human brucellosis: an overview. International Journal of Infectious Diseases, Philadelphia, v. 7, n. 3, p. 173-182, 2003.

DRAGOSAVAC, D.; TASSO, A. P.; CATALAN, M.; LEME JUNIOR, C. A. Endocardite por brucelose: relato de caso. Revista Brasileira de Terapia Intensiva, São Paulo, v. 19, n. 3, p. 354-356, 2007.

FARIA, J. F. Situação da brucelose no Brasil. Comunicações Científicas da Faculdade de Medicina Veterinária e Zootecnia da Universidade de São Paulo, São Paulo, v. 8, n. 2, p. 161-175, 1984.

FENSTERBANK, R. Brucelosis bovina, ovina y caprina: diagnóstico, control, vacunación. Scientific and Technical Review of the Office International des Epizooties, Paris, v. 5, n. 3, p. 619-633, 1986.

FERREIRA NETO, J. S. Sobre a brucelose bovina no Estado de São Paulo. Biológico, São Paulo, v. 60, n. 2, p. 1-2, 1998.
FERREIRA, C. R.; FERREIRA, C. R.; TATAGIBA, T. A.; SOUTO-FILHO, J. T. D. Espondilodiscite brucelósica: relato de caso. Revista da Sociedade Brasileira de Medicina Tropical, Uberaba, v. 35, n. 3, p. 255-258, 2002.

GIL TURNES, C.; GIRAUDO, J. A.; AMBROGI, A.; FAVA, N. Comparison of the prevalence of bovine brucellosis in open and closed herds. Zoonosis, Buenos Aires, v. 18, n. 3-4, p. 192-195, 1975.

GONÇALVES, V. S. P.; DELPHINO, M. K. V. C.; DIAS, R. A.; FERREIRA, F.; AMAKU, M.; FERREIRA NETO, J. S.; PORTO, T. B.; ALVES, C. M.; FIGUEIREDO, V. C. F.; LÔBO, J. R. Situação epidemiológica da brucelose bovina no Estado de Minas Gerais. Arquivo Brasileiro de Medicina Veterinária e Zootecnia, Belo Horizonte, v. 61, p. 35-45, 2009a. Suplemento 1.

GONÇALVES, V. S. P.; RIBEIRO, L. A.; CALDAS, R. A.; FRANCISCO, P. F. C.; DIAS, R. A.; FERREIRA, F.; AMAKU, M.; FERREIRA NETO, J. S.; FIGUEIREDO, V. C. F.; LÔBO, J. R.; BORGES, J. R. J. Situação epidemiológica da brucelose bovina no Distrito Federal. Arquivo Brasileiro de Medicina Veterinária e Zootecnia, Belo Horizonte, v. 61, p. 14-18, 2009b. Suplemento 1.

HARTIGAN, P. J. Human brucellosis: Epidemiology and clinical manifestations. Irish Veterinary Journal, London, v. 50, n. 3, p. 179-180, 1997.

HOMEM, V. S. F. Brucelose e tuberculose bovinas no município de Pirassununga, SP: prevalências, fatores de risco e estudo econômico. 2003. Tese (Doutorado em Medicina Veterinária) - Faculdade de Medicina Veterinária e Zootecnia, Universidade de São Paulo, São Paulo.

KLEIN-GUNNEWIEK, M. F. C.; AMAKU, M.; DIAS, R. A.; FERREIRA, F.; GITTI, C. B.; PEREIRA, L. A.; FIGUEIREDO, V. C. F.; LOBO, J. R.; GONÇALVES, V. S. P.; FERREIRA NETO, J. S. Situação epidemiológica da brucelose bovina no Estado do Rio de Janeiro. Arquivo Brasileiro de Medicina Veterinária e Zootecnia, Belo Horizonte, v. 61, p. 77-84, 2009. Suplemento 1.

KOUBA, V. A method of accelerated eradication of bovine brucellosis in the Czech Republic. Scientific and Technical Review of the Office International des Epizooties, Paris, v. 22, n. 3, p. 1003-1012, 2003.

LANGONI, H.; ICHIHARA, S. M.; SILVA, A. V.; PARDO, R. B.; TONIN, F. B.; MENDONÇA, F. J. P.; MACHADO, J. A. D. Isolation of Brucella spp from milk of brucellosis positive cows in São Paulo and Minas Gerais states. Brazilian Journal of Veterinary Research and Animal Science, São Paulo, v. 37, n. 6, p. 444-448, 2000. 
LAWINSKY, M. L. J.; OHARA, P. M.; ELKHOURY, M. R.; FARIA, N. C.; CAVALCANTE, K. L. J. Estado da arte da brucelose em humanos. Revista Pan-Amazônica de Saúde, Ananindeua, v. 1, n. 4, p. 75-84, 2010.

LUCAS, A. Simulação do impacto econômico da brucelose bovina em rebanhos produtores de leite das regiões Centro Oeste, Sudeste e Sul do Brasil. 2006. Tese (Doutorado em Epidemiologia Experimental e Aplicada às Zoonoses) - Universidade de São Paulo, São Paulo.

MARVULO, M. F. V.; FERREIRA, F.; DIAS, R. A.; AMAKU, M.; GROFF, A. C. M.; GONÇALVES, V. S. P.; FIGUEIREDO, V. C. F.; LÔBO, J. R.; FERREIRA NETO, J. S. Situação epidemiológica da brucelose bovina no Estado do Rio Grande do Sul. Arquivo Brasileiro de Medicina Veterinária e Zootecnia, Belo Horizonte, v. 61, p. 93-102, 2009. Suplemento 1.

MELO, C. C. F.; SOUSA, D. U.; GLORIA, F. A. C.; MOURA, L. O.; MELO, G. C. F. Espondilodiscite por brucelose: relato de caso. Revista da Sociedade Brasileira de Medicina Tropical, Uberaba, v. 40, n. 4, p. 469-472, 2007.

MIYASHIRO, S; SCARCELLI, S.; PIATTI, R. M.; CAMPOS, F. R.; VIALTA, A; KEID, L. B.; DIAS, R. A.; GENOVEZ, M. E. Detection of Brucella abortus DNA in illegal cheese from São Paulo and Minas Gerais and differentiation of B19 vaccinal strain by means of the polymerase chain reaction (PCR). Brazilian Journal of Microbiology, São Paulo, v. 38, n. 1, p. 17-22, 2007.

MORENO, E. Brucellosis in Central America. Veterinary Microbiology, Amsterdam, v. 90, n. 1-4, p. 31-38, 2002.

MOTA, A. L. A. A. Fatores de risco para brucelose bovina no Brasil. 2011. Dissertação (Mestrado em Saúde Animal) - Faculdade de Agronomia e Medicina Veterinária, Universidade de Brasília, Brasília.

NEGREIROS, R. L.; DIAS, R. A.; FERREIRA, F.; FERREIRA NETO, J. S.; GONÇALVES, V. S. P.; SILVA, M. C. P.; FIGUEIREDO, V. C. F.; LÔBO, J. R.; FREITAS, J.; AMAKU, M. Situação epidemiológica da brucelose bovina no Estado de Mato Grosso. Arquivo Brasileiro de Medicina Veterinária e Zootecnia, Belo Horizonte, v. 61, p. 56-65, 2009. Suplemento 1.

NICOLETTI, P. The epidemiology of bovine brucellosis. Advances in Veterinary Science and Comparative Medicine, Philadelphia, v. 24, n. 1, p. 69-98, 1980.

OGATA, R. A.; GONÇALVES, V. S. P.; FIGUEIREDO, V. C. F.; LÔBO, J. R.; RODRIGUES, A. L.; AMAKU, M.; FERREIRA, F.; FERREIRA NETO, J. S.; DIAS, R. A. Situação epidemiológica da brucelose bovina no Estado do Tocantins. Arquivo Brasileiro de Medicina
Veterinária e Zootecnia, Belo Horizonte, v. 61, p. 126134, 2009. Suplemento 1.

OFFICE INTERNATIONAL DES EPIZOOTIES - OIE. Brucelosis bovina, ovina y caprina. Paris: OIE, 1987. 282 p.

Brucelosis. Paris: OIE, 2013. Disponível em: $\quad<$ http://www.oie.int/es/para-los-periodistas/ enfermedades-animales/fichas-de-informacionresumidas-sobre-las-enfermedades-animales $>$. Acesso em: 20 maio 2013.

OMER, M. K.; SKJERVE, E.; WOLDEHIWET, Z.; HOLSTAD, G. Risk factors for Brucella spp. Infection in dairy cattle farms in Asmara, State of Eritrea. Preventive Veterinary Medicine, London, v. 46, n. 4, p. 257-265, 2000.

PAPPAS, G.; PAPADIMITRIOU, P.; AKRITIDIS, N.; CHRISTOU, L.; TSIANOS, E. V. The new global map of human brucellosis. The Lancet Infectious Diseases, London, v. 6, n. 2, p. 91-99, 2006.

PAULIN, L. M. S; FERREIRA NETO, J. S. O combate à brucelose bovina. Situação atual. Jaboticabal: Funep, 2003. $154 \mathrm{p}$.

PESSEGUEIRO, J.; BARATA, C.; CORREIA, J. Brucelose - uma revisão sistematizada. Medicina Interna, Lisboa, v. 10, n. 2, p. 91-100, 2003.

POESTER, F. P.; GONÇALVES, V. S. P.; LAGE, A. P. Brucellosis in Brazil. Veterinary Microbiology, Amsterdam, v. 90, n. 1-4, p. 55-62, 2002.

RAMOS, T. R. R.; PINHEIRO JUNIOR, J. W.; MOURA SOBRINHO, P. A.; SANTANA, V. L. A.; GUERRA, N. R.; MELO, L. E. H.; MOTA, R. A. Epidemiological aspects of an infection by Brucella abortus in risk occupational groups in the microregion of Araguaína, Tocantins. Brazilian Journal of Infectious Diseases, Salvador, v. 12, n. 2, p. 133-138, 2008.

ROCHA, W. V.; GONÇALVES, V. S. P.; COELHO, C. G. N. F. L.; BRITO, W. M. E. D.; DIAS, R. A.; DELPHINO, M. K. V. C.; FERREIRA, F.; AMAKU, M.; FERREIRA NETO, J. S.; FIGUEIREDO, V. C. F.; LÔBO, J. R.; BRITO, L. A. B. Situação epidemiológica da brucelose bovina no Estado de Goiás. Arquivo Brasileiro de Medicina Veterinária e Zootecnia, Belo Horizonte, v. 61, p. 27-34, 2009. Suplemento 1.

SALMAN, M. D.; MEYER, M. E. Epidemiology of bovine brucellosis in the Mexicali Valley, Mexico: literature review of disease-associated factors. American Journal of Veterinary Research, New York, v. 45, n. 8, p. 1561-1566, 1984. 
SAMARTINO, L. E. Brucellosis in Argentina. Veterinary Microbiology, Amsterdam, v. 90, n. 1-4, p. 71-80, 2002.

SANTACATARINA. Secretaria de Estado da Agricultura e da Pesca. Portaria no 17, de 20 de julho de 2012. Aprova o Regulamento Técnico do Programa de Erradicação da Brucelose Bovina e Bubalina no Estado de Santa Catarina. Diário Oficial [do] Estado, Santa Catarina, SC, $\mathrm{n}^{\circ}$ 19. 380, de 24 jul. 2012. p. 3

SANTOS, R. L.; MARTINS, T. M.; BORGES, A. M.; PAIXÃO, T. A. Economic losses due to bovine brucellosis in Brazil. Pesquisa Veterinária Brasileira, Seropédica, v. 33, n. 6, p. 759-764, 2013.

SANTOS-NETO, L. L.; COSTA, G. P.; SIMAAN, C. K.; CORREIA-LIMA, F. A. Abscesso esplênico por Brucella abortus. Revista da Sociedade Brasileira de Medicina Tropical, Uberaba, v. 32, n. 1, p. 53-55, 1999.

SHEPHERD, A. A.; SIMPSON, B. H.; DAVIDSON, R. M. An economic evaluation of the New Zealand bovine brucellosis eradication scheme. Bulletin de l'Office International des Epizooties, Paris, v. 92, n. 5-6, p. 331338, 1980.

SIKUSAWA, S.; AMAKU, M.; DIAS, R. A.; FERREIRA NETO, J. S.; MARTINS, C.; GONÇALVES, V. S. P.; FIGUEIREDO, V. C. F.; LÔBO, J. R.; FERREIRA, F. Situação epidemiológica da brucelose bovina no Estado de Santa Catarina. Arquivo Brasileiro de Medicina Veterinária e Zootecnia, Belo Horizonte, v. 61, p. 103108, 2009. Suplemento 1.

SILVA, I.; DANGOLLA, A.; KULACHELVY, K. Seroepidemiology of Brucella abortus infection in bovids in Sri Lanka. Preventive Veterinary Medicine, London, v. 46, n. 1, p. 51-59, 2000.

SILVA, V.G.S. O.; DIAS, R.A.;FERREIRA, F.;AMAKU, M.; COSTA, E. L. S.; LÔBO, J. R.; FIGUEIREDO, V. C. F.; GONÇALVES, V. S. P.; FERREIRA NETO, J. S. Situação epidemiológica da brucelose bovina no Estado de Sergipe. Arquivo Brasileiro de Medicina Veterinária e Zootecnia, Belo Horizonte, v. 61, p. 109-117, 2009. Suplemento 1.

VILLAR, K. S.; AMAKU, M.; DIAS, R. A.; FERREIRA NETO, J. S.; BENITEZ, F.; GONÇALVES, V. S. P.; FIGUEIREDO, V. C. F.; LÔBO, J. R.; FERREIRA, F. Situação epidemiológica da brucelose bovina no Estado de Rondônia. Arquivo Brasileiro de Medicina Veterinária e Zootecnia, Belo Horizonte, v. 61, p. 85-92, 2009. Suplemento 1.

VILLARROEL, M.; GRELL, M.; SAENZ, R. Isolation and identification of Brucella abortus RB 51 in human: first report in Chile. Archivos de Medicina Veterinaria, Valdivia, v. 32, n. 1, p. 89-91, 2000. 
